\title{
Indonesian Information Extraction : Challenges and Opportunities
}

\author{
Yan Puspitarani \\ Universitas Widyatama; Jalan Cikutra No. 204A Bandung, (022)7275855 \\ Informatics, Engineering Faculty Utama, Bandung \\ e-mail: yan.puspitarani@widyatama.ac.id
}

\begin{abstract}
Abstrak
Ekstraksi informasi adalah bagian dari pemrosesan bahasa alami, yang bertujuan untuk menemukan, mengambil, atau memproses informasi. Sumber data untuk ekstraksi informasi adalah teks. Teks tidak lepas dari kehidupan sehari-hari masyarakat. Melalui teks, banyak informasi rahasia dapat diperoleh. Untuk menghasilkan informasi, teks yang tidak terstruktur akan diubah menjadi data terstruktur. Ada banyak pendekatan yang dilakukan peneliti untuk proses ini. Sebagian besar penelitian tersebut dilakukan dalam Bahasa Inggris. Makalah ini menyajikan peninjauan tren penelitian terkini, tantangan, dan peluang ekstraksi informasi menggunakan bahasa Indonesia. Peninjauan ini menghasilkan peluang yang sangat bagus pada berbagai bidang industri dan pemerintahan yang dapat menunjang sistem Big Data.
\end{abstract}

Kata $\mathbf{k u n c i}$-ekstraksi informasi, natural language processing, teks terstruktur

\begin{abstract}
Information extraction is part of natural language processing, aiming to find, retrieve, or process information. The data source for information extraction is text. Text cannot be separated from people's daily lives. Through text, a lot of confidential information can be obtained. To produce information, the unstructured text will be converted into structured data. There are many approaches that researchers take to this process. Most of the studies are in English. Therefore, this paper will present the review of current research trends, challenges, and information extraction opportunities using Indonesian. This review resulted excellent opportunities in various fields of industry and government that can support Big Data systems.
\end{abstract}

Keywords - information extraction, natural language processing, text structuring

\section{INTRODUCTION}

If we look at the files in our computer directory, we will find lots of files containing text with the extension * .docx, *.pdf, or *.txt. If we open the internet, there will be much information conveyed in a text, such as news articles, tweets, or Instagram captions. Everything is information in text form and unstructured because text files are usually small in size, so they are free to store.

The amount of information in the form of text on our computers or the internet will be beneficial if we mine it. For example, suppose we collect review data for a particular product from the internet. In that case, we can determine the response of users of that product through 
Sentiment Analysis, or we can analyze more deeply from the reviewer data attributes such as age, gender, or location. Also, we can find a summary of an article or reading automatically using summarization. Or we can also get the name, location, or specific event information automatically from an article or police report using Named Entity Recognition and Event Detection.

All these intelligence processes are what text processing uses. The text processing takes advantage of word count calculations with the help of statistics or machine learning. We see this processing as our natural language in everyday life, or the term is Natural Language Processing (NLP). With NLP, we can process text in a human speaking style. Not only "bag of words" are processed in NLP, but semantics and text annotations can also be processed. The search for data relevant to the topic being searched for will be more accurate by utilizing semantics and annotations in a text. This is done by information extraction, where the meaning of the phrase is used to perform a search [1].

Information extraction is nothing new to research. There is a lot of research on this. However, there is little research to find information in Indonesian. It can be caused by the lack of a corpus and grammar in Indonesian, which is quite complicated. Therefore, this paper will discuss the information extraction approach, research trends, challenges, and opportunities regarding Information extraction in Indonesian.

The rest of this paper will describe the Information Extraction approaches current research of Indonesian Information Extraction, challenges, and opportunities summarized from current research, and finally conclusions of this paper.

\section{RECENT WORKS}

There are many information extraction studies on Indonesian based on the task. Some of them are summarized in order in the table below.

Table 1. Recent works of Indonesian Information Extraction based on the task

\begin{tabular}{|l|l|l|}
\hline \multicolumn{1}{|c|}{ Year } & $\begin{array}{c}\text { Information } \\
\text { Extraction Task }\end{array}$ & \multicolumn{1}{c|}{ Which is conducted } \\
\hline$[2]$ & Entity Extraction & $\begin{array}{l}\text { Using open NLP to detect named entities against web articles in } \\
\text { Indonesian (Finance, Politic, Sport, Health, and Technology) }\end{array}$ \\
\hline$[3]$ & NER & $\begin{array}{l}\text { I am doing Named Entity Recognition on Twitter about certain } \\
\text { events using CRF. }\end{array}$ \\
\hline$[4]$ & Extraction Event & $\begin{array}{l}\text { She was extracting information with the 5W1H concept using } \\
\text { C4.5 and AdaBoostM1 for Indonesian news articles. Kendra } \\
\text { uses BIO sequence labeling on the feature set used. }\end{array}$ \\
\hline$[5]$ & $\begin{array}{l}\text { Extracting information with the 5W1H concept of Indonesian } \\
\text { news articles using 16 features: token, token_kind, contextual, } \\
\text { morphological, pos, ne, sentence_number, location, bef-one- } \\
\text { token, bef-two-token, bef-one-pos, bef-two-pos, bef-one-ne, bef- } \\
\text { two-ne, bef-one-class, bef-two-class. In the process, Ilyas uses } \\
\text { Synthetic Minority Over-sampling (SMOTE) to handle } \\
\text { imbalanced data in the dataset. }\end{array}$ \\
\hline$[6]$ & $\begin{array}{l}\text { Conduct coreference experiments with lexical \& shallow } \\
\text { syntactic features ( appositive feature, nearest candidate feature, } \\
\text { direct sentence feature, previous and next word feature, and the } \\
\text { first person). }\end{array}$ \\
\hline resolution & Relation Extraction & Conducting open-domain information extraction using the NLP \\
\hline
\end{tabular}




\begin{tabular}{|l|l|l|}
\hline & & $\begin{array}{l}\text { pipeline and combining heuristic methods and machine learning } \\
\text { to create models, namely Logistic Regression, SVM, MLP, and } \\
\text { Random Forest. The results show that Random Forest produces } \\
\text { the best F1 score. }\end{array}$ \\
\hline$[8]$ & Relation Extraction & $\begin{array}{l}\text { Analyze some rule-based methods for Indonesian language OIE. } \\
\text { There are three features analyzed, namely: POSTag, phrase type, } \\
\text { and dependency relation type. Using the English-Indonesian } \\
\text { Parallel dataset to determine the extent to which the English } \\
\text { Open IE System can be used against Indonesian sentences. The } \\
\text { results were compared with ReVerb and OLLIE. The results } \\
\text { show that the verb-based English extraction rule is suitable for } \\
\text { use in Indonesian sentences. }\end{array}$ \\
\hline$[9]$ & $\begin{array}{l}\text { They are extracting information based on 5W1H on Indonesian } \\
\text { articles using CNN and BLSTM. The results show that CNN + } \\
\text { BLSTM produces better performance than C4.5, Ink, and Naive } \\
\text { Bayes. }\end{array}$ \\
\hline$[10]$ & $\begin{array}{l}\text { I am using DBpedia Ontology as a knowledge base for } \\
\text { information extraction on Indonesian tourism places from } \\
\text { Twitter. NER using OBIE is done to detect place names. }\end{array}$ \\
\hline$[11]$ & $\begin{array}{l}\text { Made a coreference resolution system for Indonesian using deep } \\
\text { neural network (CNN) and singleton exclusion to understand the } \\
\text { relation of 2 mentions. }\end{array}$ \\
\hline$[12]$ & $\begin{array}{l}\text { Extraction Event } \\
\text { resolution }\end{array}$ & $\begin{array}{l}\text { I am creating modeling to detect hypernym-hyponym relations } \\
\text { in Indonesian with WordNet and Wikipedia. }\end{array}$ \\
\hline
\end{tabular}

There is research that makes a system model for the Open Domain Question and Answering System for Indonesian [13]. The model he made consists of three processes: preprocessing, information extraction processing, and text processing. Meanwhile, the input to the model he made was a question about facts, and the result was a set of sentences containing answers to the questions on the input. Abdiansyah also uses Yahoo !, Bing, and Ask to search for relevant information to compare his models.

Also, the studies produced several datasets that can support the information extraction process, such as the dataset from Gultom's research [7] and Syaifudin [14], which used a dataset that has been labeled tagging for the Named Entity Recognition (NER). Also, research builds Corpus for NLP Indonesian to support information extraction, namely Fajri Koto [15], which m arouses IndoLEM, dataset NLP for Indonesian and mele $n$ gkapi dataset BERT for Language Indonesia, IndoBERT.

\section{INFORMATION EXTRACTION}

\subsection{Information Extraction Task}

The task of Information Extraction (IE) is to identify a set of predetermined concepts in a particular domain, ignoring other irrelevant information, where the domain consists of a collection of texts together with clearly defined information needs. In other words, IE is about obtaining structured factual information from unstructured text [16]. Take a look at the news article below. 
"Gempa bumi berkekuatan Magnitudo 5,0 mengguncang wilayah Kecamatan Sumur, Kabupaten Pandeglang, Banten, Sabtu (14/11/2020). Gempa tersebut terjadi pada pukul 22.32 WIB."

If we extracted the above article, it would produce the following information.

Type: Bencana

Subtype: Gempa Bumi

Location: Kecamatan Sumur, Kabuaten Pandeglang, Banten

Time: Sabtu, 14-11-2020 pukul 22:32

Magnitude: 5

The following are the essential tasks of Information Extraction (IE) [16] :

1) Named Entity Recognition (NER) addresses the problem of identification (detection) and classification of predetermined entity types, such as organizations (e.g. 'World Health Organization'), people (e.g. 'Muammar Kaddafi'), place names (e.g. , 'Baltic Sea'), temporal expressions (for example, 'September 1, 2011'), numeric and currency expressions (for example, '20 Million Euros'), etc.

2) Coreference Resolution ( $\mathrm{CO})$ is the process of identifying a collection of noun phrases that refer to the same entity. For example, consider the sentence in the image below.

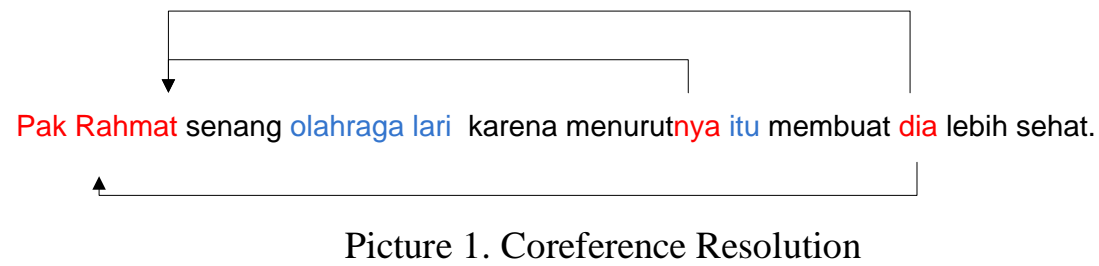

In the example sentence above, when two words are coreferential, the affix "-nya" to the word " menurutnya" is a pronoun that replaces the word "Pak Rahmat," which was mentioned at the beginning of the sentence. Also, the word "dia" is a pronoun that refers to "Pak Rahmat." Then the word " itu" also refers to the word "olahraga lari." The coreferential resolution process above should identify that "menurutnya" and "dia" refers to "Pak Rahmat." In other words, the system must produce \{mennurutnya and Pak Rahmat\}, \{dia and Pak Rahmat\}, and \{itu and olahraga lari \}.

3) Relationship Extraction (RE) is the task of detecting and classifying predetermined relationships between entities identified in the text. For example, Bandung and Jawa Barat entities have a 'located at' relationship. Usually, RE is represented by a tuple.

4) Event Extraction (EE) refers to the task of identifying events in free text and obtaining detailed and structured information about them, ideally identifying who does what to whom, when, where, through what methods (instruments), and why.

\subsection{Information Extraction Technique}

Based on the results of a survey conducted by Monnia Mannai [17], there are two approaches to information extraction techniques: necessary IE and semantic-based IE. 


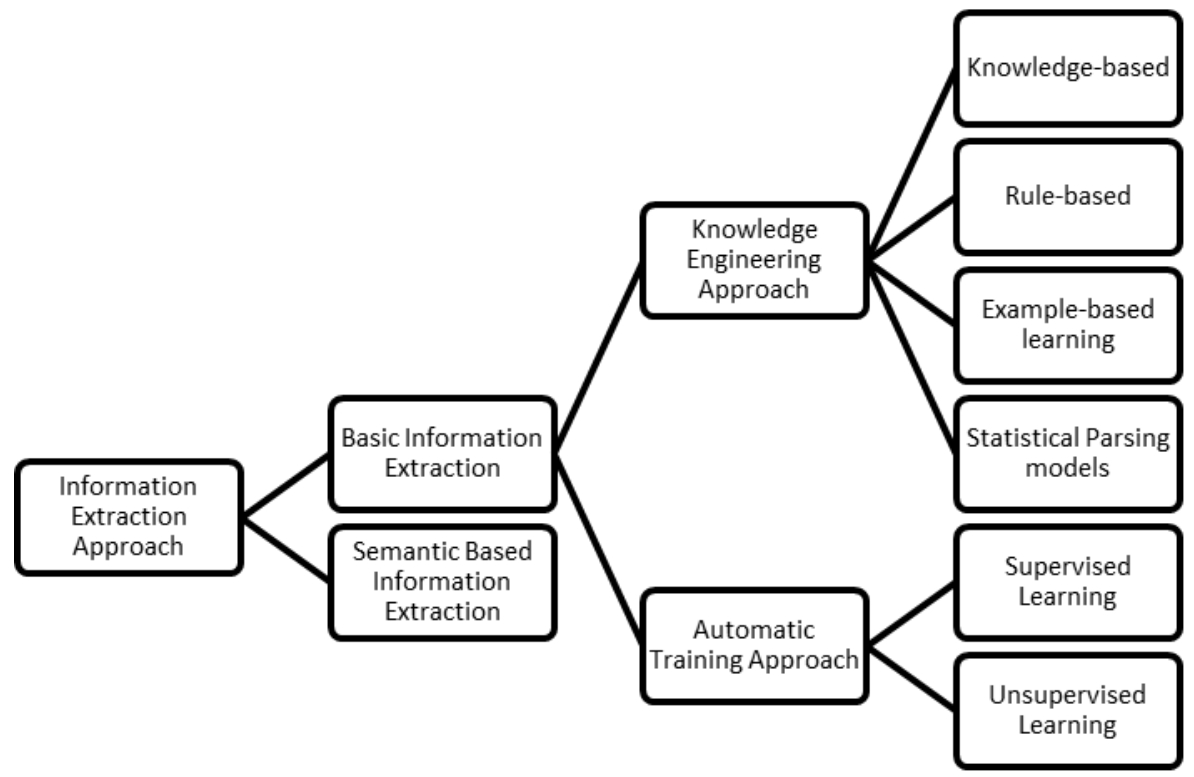

Picture 2. Information Extraction Approach

\subsubsection{Basic Approach of Information Extraction}

Basic IE is divided into two approaches [18], namely the knowledge engineering approach and the automatic training approach, as described in the chart above.

\subsubsection{Knowledge of Engineering-Based Approach}

According to Debenham (1988), knowledge engineering is the process of building a knowledge-based system in various fields, be it the public or private sector in the field of trade or industry. Meanwhile, a knowledge knowledge-based system is a computer program designed to mimic experts' work in a particular field of knowledge [19]. This approach is widely used in computer science, which requires knowledge of human thinking in it, for example, Expert Systems, Data Mining that produces rules, Geographical Information Systems, and so on [17]. This approach is often referred to as a rule-based approach. Therefore, this approach will cost quite a lot because the construction of rules requires a long iteration process.

This approach is divided into the following sub-models:
a. knowledge-based
b. Rule-based approach
c. Example-based learning
d. Statistical parsing models

\subsubsection{Automatic Training Approach}

This approach is often known as Machine Learning. In this approach, a training process is carried out from a data source to look for rules. The process in machine learning is more adaptive because the rules' results will change according to the trend of the data entered in the training process.

Machine learning in Information Extraction will require Natural Language Processing and annotated data sources as performed by Gultom [7], using NLP and text annotations source, which is the result of gluematisasi, POS Tag, NER, and dependency relations. Many Machine Learning algorithms can be used for information extraction, especially in Indonesian, namely SVM, Random Forest, Multi-Layer Perceptron [7], CNN, C45, Naive Bayes [9], and Deep learning [11]. 
Two types of learning can be done with a Machine Learning approach, namely, Supervised and Unsupervised. The supervised approach will produce a predictive model from labeled data sources through the training process. The label used must have been defined by an expert who understands the data. This supervised approach is usually called a classifier. Meanwhile, the unsupervised approach will look for confidential information based on data objects with similarities to the data source. Using this approach, data sources without labels can be processed.

\subsubsection{Semantic Approach of Information Extraction}

In natural language, every word and phrase has a meaning. Sometimes some words are ambiguous, so they have different meanings when applied to sentences. Problems like this will occur in determining the relationship between words. Therefore, a semantic approach to information extraction is needed.

The extraction of information from texts can build fact databases and knowledge bases for various purposes. These applications require accurate identification of the semantic relations in the text so that the concepts extracted from a text can be connected with the relations to form a coherent unity [1].

In the process, it is necessary to do pattern matching to determine the relation of a phrase. Khoo describes the primary process for recognizing semantic relations automatically using pattern matching. Pattern matching is done to recognize pieces of text or phrases or sentences that match a given pattern. If appropriate, it is said that the text fragments contain semantic relationships associated with these patterns [1].

One of the studies that use this semantic method in Indonesian is Rosyiq [10], who uses DBpedia Ontology as knowledge based for extracting information on Indonesian tourism places from Twitter. Rosyik performed Named Entity Recognition using Ontology-Based Information Extraction (OBIE) to detect place names. OBIE is an Information Extraction technique that uses ontology as a guide in the process and produces information in the form of ontology. The ontology contains a formal and conceptual explicit specification of data. The other OBIE process can be seen from a survey conducted by Wimalasuriya [20].

\section{CHALLENGES AND OPPORTUNITIES}

As explained in the previous section, there have been many studies on Information Extraction in Indonesian that has been carried out. These studies have used various existing techniques, ranging from essential to semantic approaches. Based on each technique's characteristics, it can be concluded how to choose the right technique according to the data sources that are owned as follows.

1. Use knowledge base if you have data sources in the form of lexicons or lists, recruit rule makers, training data is scarce or too expensive to collect, extract specifications that change frequently, and require excellent system performance [16].

2. Use a training approach if the data source is not available, does not require expert rule makers, has a lot of training data that is easy to obtain, has stable extraction specifications, and does not prioritize system performance [16].

3. Use semantic-based if the task to be done considers the meaning of the sentence or the relationship between sentences to be an essential part of extracting information. This approach is commonly used for event extraction and relation extraction.

Based on the research on Indonesian information extraction that has been carried out, we can take advantage of the Information Extraction task in various fields in Indonesia. The trend of Big Data in text data can be realized by utilizing Business Intelligence and Social Media Analysis. 
It would be a good opportunity in the field of sales through the marketplace if all data from reviews on social media, search keywords, activities, and user locations in the marketplace are extracted using NER to generate a summary of user needs, sales trends, user distribution, and so on automatically with utilizing Business Intelligence and Social Media Analysis.

Through information extraction also we can build the Information Retrieval System and Question and Answer system more relevant to the search keywords by using highly dependent on many factors, such as the relevant information generated by the search engine, the target language, text processing tool (e.g., noise removal, parser, sentence tokenization, NER, syntactic, similarity function, etc.), and system infrastructure (network connection, processing unit, etc.) as modeled by Abdiansyah [13]. This system will be beneficial in education.

In the government sector, information extraction would be an excellent opportunity to digitize administrative services. Storing data for incoming letters to an agency in a more structured manner can be done automatically. The database of letter data storage results can also be summarized using Business Intelligence.

Apart from that, we can also automatically analyze an event's chronology in a news article by using event detection on Information retrieval. The police can also use this in carrying out investigations of criminal records.

However, from the opportunities mentioned above, there are still challenges in making it happen. The lack of a complete Indonesian language corpus makes the accuracy of the information extraction results imperfect. There is still a need for an Indonesian language corpus adapted to the object of research because the grammatical characteristics of Indonesian for each object are not the same. For example, slang and informal Indonesian grammar are widely used on social media, where the majority are millennials. Then, more critical language and lots of sentences are directly used in news articles. Also, formal grammar and sometimes have terms that are not commonly found in letters. This makes identification and semantics more expensive to process.

\section{CONCLUSION}

This paper has provided an overview of the Information Extraction approach and several research trends that have been carried out using Indonesian. It has also been explained how to determine the approach based on specific criteria and previous research results.

Information extraction using Indonesian can be a good opportunity in various fields such as the marketplace, information retrieval, question and answering systems, administration, and police. It is primarily associated with the current Big Data trend. However, the challenge that remains to be faced is that not many Corpus can handle the Indonesian natural language, which has different characteristics for each field. So that research still needs to be done, especially on the formation of the Indonesian Language Corpus.

\section{ACKNOWLEDGMENT}

This research is funded by PDP DIKTI 2020.

\section{REFERENCES}


[1] S. H. Khoo, Christopher;Myaeng, "Identifying semantic and syntactic relations from text documents," Proc. - 2015 IEEE RIVF Int. Conf. Comput. Commun. Technol. Res. Innov. Vis. Futur. IEEE RIVF 2015, pp. 127-131, 2015, doi: 10.1109/RIVF.2015.7049887.

[2] T. Mangasi, A. Erwin, and H. P. Ipung, "Defined entity extraction based on Indonesian text document," Proc. - 2014 Int. Conf. ICT Smart Soc. "Smart Syst. Platf. Dev. City Soc. GoeSmart 2014”, ICISS 2014, pp. 61-65, 2014, doi: 10.1109/ICTSS.2014.7013152.

[3] F. Muhammad and M. L. Khodra, "Event information extraction from Indonesian tweets using conditional random field," ICAICTA 2015 - 2015 Int. Conf. Adv. Informatics Concepts, Theory Appl., pp. 0-5, 2015, doi: 10.1109/ICAICTA.2015.7335383.

[4] M. L. Khodra, "Event extraction on Indonesian news article using multiclass categorization," ICAICTA 2015 - 2015 Int. Conf. Adv. Informatics Concepts, Theory Appl., pp. 1-5, 2015, doi: 10.1109/ICAICTA.2015.7335365.

[5] M. L. Ilyas, Ridwan; Khodra, "Ekstraksi Informasi 5W1H Kumpulan Berita Online Bahasa Indonesia," J. Cybermatika, 2015.

[6] G. J. Suherik and A. Purwarianti, "Experiments on coreference resolution for Indonesian language with lexical and shallow syntactic features," 2017 5th Int. Conf. Inf. Commun. Technol. ICoIC7 2017, vol. 0, no. c, 2017, doi: 10.1109/ICoICT.2017.8074648.

[7] Y. Gultom and W. C. Wibowo, "Automatic open domain information extraction from Indonesian text," Proc. - WBIS 20172017 Int. Work. Big Data Inf. Secur., vol. 2018Janua, pp. 23-30, 2018, doi: 10.1109/IWBIS.2017.8275098.

[8] A. Romadhony, A. Purwarianti, and D. H. Widyantoro, "Rule-based Indonesian Open Information Extraction," ICAICTA 2018 - 5th Int. Conf. Adv. Informatics Concepts Theory Appl., pp. 107-112, 2018, doi: 10.1109/ICAICTA.2018.8541293.

[9] A. Nurdin and N. U. Maulidevi, "5W1H Information Extraction with CNN-Bidirectional LSTM," in Journal of Physics: Conference Series, 2018, vol. 978, no. 1, doi: 10.1088/1742-6596/978/1/012078.

[10] A. Rosyiq, A. R. Hayah, A. N. Hidayanto, M. Naisuty, A. Suhanto, and N. F. Avuning Budi, "Information Extraction from Twitter Using DBpedia Ontology: Indonesia Tourism Places," in Proceedings - 1st International Conference on Informatics, Multimedia, Cyber and Information System, ICIMCIS 2019, 2019, pp. 91-96, doi: 10.1109/ICIMCIS48181.2019.8985194.

[11] T. Auliarachman and A. Purwarianti, "Coreference Resolution System for Indonesian Text with Mention Pair Method and Singleton Exclusion using Convolutional Neural Network," Proc. - 2019 Int. Conf. Adv. Informatics Concepts, Theory, Appl. ICAICTA 2019, pp. 3-7, 2019, doi: 10.1109/ICAICTA.2019.8904261.

[12] M. N. Nityasya, R. Mahendra, and M. Adriani, "Hypernym-Hyponym Relation Extraction from Indonesian Wikipedia Text," Proc. 2018 Int. Conf. Asian Lang. Process. IALP 2018, pp. 285-289, 2019, doi: 10.1109/IALP.2018.8629216. 
[13] A. ABDIANSAH and A. S. UTAMI, "Information Extraction from Web as Knowledge Resources for Indonesian Question Answering System," 2020, vol. 172, no. Siconian 2019, pp. 419-425, doi: 10.2991/aisr.k.200424.064.

[14] Y. Syaifudin, "Quotations Identification From Indonesian Online News Using Rule-based Method," in 2016 Internation Seminar on Intelligent Technology and Its Application, 2016, pp. 187-194, doi: 10.1109/ISITIA.2016.7828656.

[15] F. Koto, A. Rahimi, J. H. Lau, and T. Baldwin, "IndoLEM and IndoBERT: A Benchmark Dataset and Pre-trained Language Model for Indonesian NLP," 2020, [Online]. Available: http://arxiv.org/abs/2011.00677.

[16] H. Saggion and T. Poibeau, "Multi-source, Multilingual Information Extraction and Summarization," pp. 3-21, 2013, doi: 10.1007/978-3-642-28569-1.

[17] M. Mannai, W. B. A. Karâa, and H. H. Ben Ghezala, "Information extraction approaches: A survey," Adv. Intell. Syst. Comput., vol. 625, pp. 289-297, 2018, doi: 10.1007/978-98110-5508-9_28.

[18] D. E. Appelt, "Introduction to Information Extraction," AI Commun., vol. 12, no. 3, pp. 161-172, 1999.

[19] S. Pradhan, "An Introduction to Knowledge Engineering," An Introd. to Knowl. Eng., pp. 1-25, 2007, doi: 10.1007/978-1-84628-667-4_1.

[20] D. C. Wimalasuriya and D. Dou, "Ontology-based information extraction: An introduction and a survey of current approaches," J. Inf. Sci., vol. 36, no. 3, pp. 306-323, 2010, doi: $10.1177 / 0165551509360123$. 